JPE (Jurnal Pendidikan Edutama) Vol. 7 No. 1 Januari 2020

P-ISSN : 2339-2258 (Print) E-ISSN: 2548-821X (Online)

http://ejurnal.ikippgribojonegoro.ac.id/index.php/JPE

\title{
PENGARUH MINAT BELAJAR DAN LINGKUNGAN KELUARGA TERHADAP PRESTASI BELAJAR SISWA PADA MATA PELAJARAN EKONOMI BISNIS KELAS X SMK PGRI 2 BOJONEGORO
}

\author{
Sarjono $^{1}$, FiFi Zuhriah ${ }^{2}$, Siti Herawati Nur Hidayah. ${ }^{3}$ \\ ${ }^{1}$ Fakultas Pendidikan dan Ilmu Pengetahuan Sosial, IKIP PGRI Bojonegoro \\ ${ }^{2}$ Fakultas Pendidikan dan Ilmu Pengetahuan Sosial, IKIP PGRI Bojonegoro \\ ${ }^{3}$ Fakultas Pendidikan dan Ilmu Pengetahuan Sosial, IKIP PGRI Bojonegoro \\ Email: sarjonoikippgribjn@ gmail.com ${ }^{1)}$
}

\begin{abstract}
Abstrak: This research aims to determine: (1) the effect of learning interest on student learning achievement, (2) the influence of the family environment on student learning achievement, and (3) the simultaneous influence between learning interest and the family environment towards student learning achievement in business economics subjects.This research uses quantitative research. Population af this research are all the students of class X SMK PGRI 2 Bojonegoro consists of 101 students. Sampling technique that used in this research is proportional random sampling technique which obtained a total sample of 81 students. This research uses questionaries and documentation method to collected data. The results showed that: (1) There was a positive and significant influence between learning interest on student achievement on business economics subjects (2) There is a positive and significant influence between the family environment on student achievement on business economics. (3) There is a positive and significant influence between interest in learning and the family environment simultaneously on student achievement in the subjects of business economics.
\end{abstract}

Keywords: Learning Interest, Family Environment, Student Learning Achievement

Abstrak: Penelitian ini bertujuan untuk mengetahui: (1) pengaruh minat belajar terhadap prestasi belajar siswa,, (2) pengaruh lingkungan keluarga terhadap prestasi belajar siswa, dan (3) pengaruh secara simultan antara minat belajar dan lingkungan keluarga terhadap prestasi belajar siswa pada mata pelajaran ekonomi bisnis. Penelitian ini menggunakan metode penelitian kuantitatif. Popoulasi penelitian ini adalah semua siswa kelas X SMK PGRI 2 Bojonegoro sejumlah 101 siswa. Teknik sampling yang digunakan dalam peneletian ini adalah proportional random sampling dengan jumlah sampel sebanyak 81 siswa. Penelitian ini menggunakan metode angket dan dokumentasi untuk mengumpulkan data. Hasil penelitian menunjukkan bahwa : (1) Ada pengaruh positif dan signifikan antara minat belajar terhadap prestasi belajar siswa pada mata pelajaran ekonomi. (2) Ada pengaruh positif dan signifikan antara lingkungan keluarga terhadap prestasi belajar siswa pada mata pelajaran ekonomi bisnis. (3) Ada pengaruh positif dan signifikan antara minat belajar dan lingkungan keluarga secara simultan terhadap prestasi belajar siswa pada mata pelajaran ekonomi.

Kata kunci: Minat Belajar, Lingkungan Keluarga, Prestasi Belajar Siswa. 


\section{PENDAHULUAN}

Di era globalisasi ini pendidikan sangatlah penting bagi kelangsungan hidup manusia. Karena pendidikan merupakan sesuatu yang dapat mempersiapkan seseorang untuk memperoleh kesuksesan di masa depan, salah satunya dengan menempu pendidikan sekolah. Pendidikan bukan lah hal yang mudah untuk dicapai dan itu membutuhkan kesungguhan dan keseriusan untuk dapat mencapainya. Seorang siswa dikatakan berhasil mencapai suatu proses pendidikan apablia telah melalui serangkaian proses belajar di sekolah, dan prestasi belajar siswa mengalami peningkatan dan perkembangan.

Pemasalahan yang sering muncul adalah prestasi belajar siswa yang masih rendah dan belum tercapai secara optimal. Hal ini menjadi masalah yang banyak ditemui oleh semua guru untuk mencapai keberhasilan dalam proses kegiatan belajar mengajar. Banyak faktor yang mempengaruhi prestasi belajar siswa menurut Slameto (2010: 54 - 69) menyatakan bahwa faktor yang mempengaruhi prestasi belajar siswa dibedakan menjadi 2 yaitu faktor intern atau faktor yang ada dalam diri yang sedang belajar dan faktor ekstern atau faktor yang ada luar individu. Salah satu faktor intern yang mempengaruhi prestasi belajar siswa adalah minat belajar. Menurut Slameto (2010: 180) “ Minat adalah salah satu rasa lebih suka dan ketertarikan pada suatu hal atau aktivitas, tanpa ada yang menyuruh".

Dalam kegiatan proses pembelajaran minat mempunyai aspek yang sangat penting karena minat dapat memberikan semangat kepada siswa dalam kegiatan belajaranya. Maka peneliti mengambil faktor intern minat belajar sebagai variabel independen pertama karena tanpa adanya minat belajar yang tumbuh dari dalam diri siswa maka dalam proses pembelajaran berlangsung siswa tersebut kurang bisa berkosentrasi dalam belajar, sehingga menyebabkan materi yang disampaikan oleh guru kurang dipahami dan tidak tersimpan dalam ingatan siswa. Dan siswa juga akan mengalami kesulitan dalam belajarnya, hal ini akan berdampak pada hasil prestasi belajar siswa yang kurang optimal.

Jika seorang siswa tidak memiliki minat yang tinggi dan tidak merasa senang terhadap objek yang akan dipelajarinya maka akan sulit diharapkan baginya untuk lebih tekun dalam belajar. Sebaliknya jika seorang siswa tersebut belajar dengan minat yang tinggi dan merasa senang terhadap objek yang dipelajarinya maka ia akan memperoleh prestasi belajar yang baik dan memuaskan.

Minat terhadap mata pelajaran yang dimiliki oleh seseorang bukan bawaan sejak lahir, tetapi minat akan muncul dengan sendirinya melalui proses peniliaian afektif dan kognitif serta dengan seiring berjalannya waktu. Minat yang tinggi untuk belajar mata pelajaran ekonomi dan bisnis yang timbul dari diri siswa diharapkan dapat meningkatkan prestasi belajar siswa yang ditunjukkan adanya perasaan senang dalam diri siswa ketika belajar khususnya pada mata pelajaran ekonomi.

Faktor ekstern juga berpengaruh terhadap prestasi belajar siswa, salah satunya adalah lingkungan keluarga. Peneliti mengambil lingkungan keluarga karena didalam lingkungan keluarga sangat diperlukan figur orang tua yang berperan aktif untuk anakanaknya dalam memberikan pendidikan. Orang tua juga harus memberikan perhatian kepada anak, membantu dan mengawasi anak pada saat anak mengerjakan tugas 
maupun sedang belajar. Dan keluargalah yang harus menyiapkan suatu perkembangan dan pembentukan karakter seorang anak sejak dini. Keadaan keluarga yang kurang harmonis, orang tua kurang perhatian terhadap prestasi belajar siswa dan keadaan ekonomi yang lemah atau berlebihan bisa menyebabkan turunnya prestasi belajar anak (Hamalik, 2001: 194).

Dengan perkembangan zaman yang begitu cepat ini, sering kali dalam kenyataan yang kita jumpai suatu pergeseran mengenai peran dan fungsi orang tua dalam sebuah keluarga khususnya terhadap pendidikan anaknya anaknya mulai berubah. Untuk mengingatkan anak mereka untuk belajar atau hanya sekedar mendampingi mereka belajar pun tidak pernah, mereka hanya memenuhi kebutuhan dari segi finansialnya saja tanpa ikut serta dalam mengawasi dan mendampingi anaknya untuk belajar. Hal ini disebabkan karena kesibukan orang tua mereka masingmasing sehingga mereka kurang memperhatika belajar anak.

Minat belajar mempunyai peranan yang sangat penting dalam proses belajar seorang siswa. Tanpa adanya sebuah minat belajar yang tinggi dan timbul dari diri siswa itu sendiri terhadap objek yang akan dipelajarinya maka sulit untuk mendapatkan prestasi belajar yang baik, dan apabila siswa tersebut belajar dengan minat yang tinggi terhadap objek yang akan dipelajarinya maka siswa tidak akan mengalami kesulitan dalam belajar dan tentunya mendapatkan prestasi belajar yang baik. Minat belajar ini juga harus didukung oleh lingkungan keluarga yang baik pula agar siswa terdorong untuk terus tetap semangat dalam kegiatan belajar sehingga hasil prestasi belajar siswa akan optimal.

Tujuan yang ingin dicapai oleh penulis dari penelitian ini sebagai berikut : (1) Untuk mengetahui pengaruh antara minat belajar terhadap prestasi belajar siswa pada mata pelajaran ekonomi bisnis kelas X SMK PGRI 2 Bojonegoro; (2)Untuk mengetahui pengaruh antara lingkungan keluarga terhadap prestasi belajar siswa pada mata pelajaran ekonomi bisnis kelas X SMK PGRI 2 Bojonegoro; (3) Untuk mengetahui pengaruh secara simultan antara minat belajar dan lingkungan keluarga terhadap prestasi belajar siswa pada mata pelajaran ekonomi bisnis kelas X SMK PGRI 2 Bojonegoro.

\section{METODE PENELITIAN}

Metode penelitian adalah suatu cara untuk mendapatkan data dengan tujuan tertentu. metode penelitian yang digunakan dalam penelitian ini yaitu metode penelitian kuantitatif. Dan untuk jenis penelitian ini menggunakan jenis penelitian kuantitatif asosiatif kausal. Populasi dalam penelitian ini adalah seluruh siswa kelas X SMK PGRI 2 Bojonegoro yang berjumlah 101 siswa. Sampel dalam penelitian ini sebanyak 81 siswa ditentukan dengan teknik proportional random sampling.

Teknik pengumpulan data dengan menggunakan angket untuk variabel minat belajar dan lingkungan keluarga serta dokumentasi untuk variabel prestasi belajar. Pengujian instrumen dilakukan dengan menggunakan uji validitas dan uji reliabilitas. Teknik analisis data dalam penelitian ini menggunakan uji asumsi klasik, analisis regresi ganda dan uji hipotesis.

\section{HASIL DAN PEMBAHASAN}

\section{Hasil Uji Asumsi Klasik \\ a. Uji Normalitas}

Uji normalitas bertujuan untuk mengetahui apakah model regresi memiliki distribusi normal atau tidak. Uji normalitas ini dilakukan dengan uji Kolmogorov-Smirnov ( $K$ $S$ ) dengan taraf signifikan 5\% dengan 
bantuan program SPSS versi 16 for windows.

Berdasarkan hasil pengujian menunjukkan bahwa nilai Kolmogorov-Smirnov sebesar 0,823 dan nilai Asymp. Sig(2-tailed) menunjukkan angka sebesar 0,508 artinya nilai signifikansi $>\alpha(0,05)$ atau 0,508 lebih besar dari 0,05 , maka dapat disimpulkan bahwa seluruh variabel memiliki distribusi normal.

\section{b. Uji Multikolinearitas}

Uji multikolineritas adalah uji yang digunakan untuk menguji apakah model regresi ditemukan adanya korelasi antar variabel bebas (Ghozali ,2011:15). Dan perhitungannya dilakaukan dengan bantuan program SPSS versi 16 for windows.

Berdasarkan hasil perhitungan diperoleh bahwa hasil variabel minat belajar dan lingkungan keluarga memiliki nilai tolerance sebesar 0,827atau 0,827 lebih besar dari 0,1 dan nilai VIF sebesar 1,209 atau 1,209 lebih kecil dari 10, maka dapat disimpulkan bahwa tidak terjadi multikolineritas dalam model regresi ini.

\section{c. Uji Heterokedastisitas}

Uji heterokedastisitas bertujuan untuk menguji apakah dalam suatu model regresi terjadi ketidaksamaan variabel dari residu suatu pengamatan ke pengamatan yang lain. Uji heterokedastisitas ini dilakukan dengan uji glejser, dengan bantuan program SPSS versi 16 for windows.

Berdasarkan hasil perhitung an diperoleh bahwa hasil dari nilai signifikansi minat belajar sebesar 0,134 lebih besar dari $\alpha(0,05)$ dan lingkungan keluarga sebesar 0,086 lebih besar dari $\alpha(0,05)$. Dengan demikian dapat disimpulkan bahwa tidak terjadi masalah heterokedastisitas pada model regresi ini.

\section{Analisis Regresi Ganda}

Analisis regresi berganda dilakukan untuk mengetahui seberapa besar pengaruh dari variabel independen terhadap variabel dependen baik secara parsial maupun simultan. Perhitungan ini dilakukan dengan bantuan program SPSS versi 16.0 for windows dan dapat dilihat pada tabel di bawah ini :

Tabel 4.6

Analisis regresi berganda

Coefficients $^{\mathrm{a}}$

\begin{tabular}{|c|c|c|c|c|c|}
\hline \multirow[b]{2}{*}{ Model } & \multicolumn{2}{|c|}{$\begin{array}{l}\text { Unstandardized } \\
\text { Coefficients }\end{array}$} & \multirow{2}{*}{\begin{tabular}{|c|}
$\begin{array}{c}\text { Standardized } \\
\text { Coefficients }\end{array}$ \\
Beta \\
\end{tabular}} & \multirow[t]{2}{*}{$\mathrm{t}$} & \multirow[t]{2}{*}{ Sig. } \\
\hline & B & Std. Error & & & \\
\hline 1 (Constant) & $\begin{array}{r}71.0 \\
27\end{array}$ & 11.128 & & 6.383 & .000 \\
\hline $\begin{array}{l}\text { Minat } \\
\text { Belajar }\end{array}$ & .681 & .189 & .404 & 3.599 & .001 \\
\hline $\begin{array}{l}\text { Lingkungan } \\
\text { Keluarga }\end{array}$ & .590 & .167 & .397 & 3.537 & .001 \\
\hline
\end{tabular}

a. Dependent Variable: Prestasi Belajar Siswa

Berdasarkan hasil perhitungan pada tabel 4.6 diatas menunjukkan hasil bahwa nilai konstanta sebesar 71,027 dan koefisien untuk variabel minat belajar $\left(X_{1}\right)$ memiliki nilai sebesar 0,681 dan koefisien variabel lingkungan keluarga $\left(X_{2}\right)$ memiliki nilai sebesar 0,590 . Sehingga persamaan regresinya yaitu :

$Y=71,027+0,681 X_{1}+0,590 X_{2}$

Dari persamaan tersebut dapat dijelaskan bahwa Konstanta (a) sebesar 71,027 artinya apabila variabel minat belajar $\left(X_{1}\right)$ dan lingkungan keluarga $\left(X_{2}\right)$ nilainya tetap (konstan), maka variabel prestasi belajar siswa $(Y)$ nilainya akan meningkat sebesar 71,027. Koefisien variabel minat belajar $\left(X_{1}\right)$ sebesar 0,681 artinya jika setiap ada penambahan $1 \%$ pada variabel minat belajar, maka variabel prestasi belajar (Y) akan mengalami peningkatan sebesar 0,681 dengan asumsi bahwa variabel bebas yang lain dari model regresi adalah tetap. Koefisien variabel lingkungan 
keluarga $\left(X_{2}\right)$ sebesar 0,590 artinya jika setiap ada penambahan $1 \%$ pada variabel lingkungan keluarga, maka variabel prestasi belajar siswa akan mengalami penurunan sebesar 0,590 dengan asumsi bahwa variabel bebas yang lain dari model regresi adalah tetap.

\section{Uji Hipotesis}

\section{a. Uji signifikan parsial ( Uji t )}

Uji signifikansi parsial dilakukan untuk mengetahui ada tidaknya pengaruh dari masing-masing variabel bebas terhadap variabel terikat. Dalam pengujian ini dilakukan dengan bantuan program SPSS versi 16 for windosw dengan taraf signifikan sebesar 5\% atau $\alpha=$ 0,05 .

Tabel 4.7

Hasil Uji t

Coefficients $^{\mathrm{a}}$

\begin{tabular}{|l|r|r|c|c|c|}
\hline & \multicolumn{2}{|c|}{$\begin{array}{c}\text { Unstandardized } \\
\text { Coefficients }\end{array}$} & $\begin{array}{c}\text { Standardized } \\
\text { Coefficients }\end{array}$ & $\mathrm{t}$ & Sig. \\
\cline { 2 - 6 } & \multicolumn{1}{|c|}{$\begin{array}{c}\text { Std. } \\
\text { Model }\end{array}$} & \multicolumn{1}{c|}{ Brror } & Beta & & \\
\hline 1 (Constant) & $\begin{array}{r}71.02 \\
7\end{array}$ & 11.128 & & 6.383 & .000 \\
$\begin{array}{l}\text { Minat } \\
\text { Belajar } \\
\begin{array}{l}\text { Lingkungan } \\
\text { Keluarga }\end{array}\end{array}$ & .681 & .189 & .404 & 3.599 & .001 \\
\hline
\end{tabular}

Hasil untuk variabel minat belajar $\left(X_{1}\right)$ diperoleh nilai sig sebesar 0,001 , nilai signifikan ini lebih kecil dari nilai $\alpha 0,05$ dan variabel $\left(X_{1}\right)$ mempunyai hasil $t_{\text {hitung }}$ sebesar 3,599 dengan $t_{\text {tabel }}$ sebesar 1,991 atau 3,599>1,991, sehingga dapat disimpulkan $\mathrm{H}_{\mathrm{O}}$ ditolak dan $\mathrm{H}_{\mathrm{a}}$ diterima yang artinya bahwa " Ada pengaruh antara minat belajar terhadap prestasi belajar siswa pada mata pelajaran ekonomi bisnis kelas X SMK PGRI 2 Bojonegoro".

Sedangkan untuk variabel lingkungan

keluarga $\left(X_{2}\right)$ diperoleh nilai signifikan sebesar 0,001 lebih kelcil dari nilai $\alpha \quad 0,05$ atau $0,001<0,05$ dan dengan hasil $t_{\text {hitung }}$ sebesar 3,537 dibandingkan dengan $t_{\text {tabel }}$ sebesar 1,991 atau 3,537>1,991, sehingga dapat disimpulkan $\mathrm{H}_{\mathrm{O}}$ ditolak dan $\mathrm{H}_{\mathrm{a}}$ diterima yang artinya bahwa " Ada pengaruh lingkungan keluarga terhadap prestasi belajar siswa pada mata pelajaran ekonomi bisnis kelas $\mathrm{X}$ SMK PGRI 2 Bojonegoro".

b. Uji signifikansi simultan ( Uji F)

Uji F ini dilakukan untuk mengetahui apakah semua variabel independen yaitu minat belajar dan lingkungan keluarga secara bersamasama atau simultan mempengaruhi variabel dependen yaitu prestasi belajar siswa. Dengan cara membandingkan nilai probalitas dengan taraf signifikan 0,05. Berdasarkan hasil perhitungan dengan bantuan SPSS 16.0 for windows dapat dilihat alam tabel ANOVA berikut ini :

Tabel 4.8

Hasil Uji F

ANOVAb

\begin{tabular}{|c|c|c|c|c|c|}
\hline Model & $\begin{array}{l}\text { Sum of } \\
\text { Squares }\end{array}$ & $\mathrm{df}$ & $\begin{array}{l}\text { Mean } \\
\text { Square }\end{array}$ & $\mathrm{F}$ & Sig. \\
\hline 1 Regression & 645.352 & 2 & 322.676 & 8.996 & $.000 \mathrm{a}$ \\
\hline Residual & 2797.710 & 78 & 35.868 & & \\
\hline Total & 3443.062 & 80 & & & \\
\hline
\end{tabular}

b. Dependent Variable: Prestasi Belajar Siswa

Berdasarkan tabel 4.8 diatas menunjukkan bahwa hasil nilai signifikan sebesar 0,000 lebih kecil dari nilai alpha sebesar 0,05 atau $0,000<0,05$. Dengan $F$ tabel sebesar 3,114 dan dan $F_{\text {nitung }}$ sebesar 8,996 atau 8,996 lebih besar dari 3,114.

Hal ini menunjukkan bahwa $\mathrm{H}_{\mathrm{O}}$ ditolak dan $\mathrm{H}_{\mathrm{a}}$ diterima yang artinya bahwa "Ada pengaruh secara simultan antara minat belajar dan lingkungan keluarga terhadap prestasi belajar siswa pada mata 
pelajaran ekonomi bisnis kelas $\mathrm{X}$ SMK PGRI 2 Bojonegoro.

\section{Koefisien Determinasi $\left(\boldsymbol{R}^{2}\right)$}

Koefisien determinasi secara simultan adalah besarnya nilai konstribusi variabel independen secara keseluruhan yang digunakan untuk mengukur seberapa jauh kemampuan model dalam menerangkan variasi variabel dependen (Ghozali, 2011: 97). Adapun hasil perhitungan koefisien determinasi secara simultan $\left(R^{2}\right)$ dengan bantuan program SPSS versi 16 for windows dapat dilihat berdasarkan tabel dibawah ini :

Tabel 4.10
Koefisien determinasi secara simultan $\left(\boldsymbol{R}^{\mathbf{2}}\right)$
Model Summary
\begin{tabular}{|l|r|r|r|r|}
\hline Model & $\mathrm{R}$ & $\begin{array}{c}\mathrm{R} \\
\text { Square }\end{array}$ & $\begin{array}{c}\text { Adjusted R } \\
\text { Square }\end{array}$ & $\begin{array}{c}\text { Std. Error of the } \\
\text { Estimate }\end{array}$ \\
\hline 1 & $.433^{\mathrm{a}}$ & .187 & .167 & 5.989 \\
\hline
\end{tabular}
a. Predictors: (Constant), Lingkungan Keluarga, Minat Belajar

Berdasarkan hasil perhitungan diperileh nilai $\mathrm{R}$ Square sebesar 0,187 . Hasil ini berarti bahwa variabel minat belajar dan lingkungan keluarga secara bersamasama mempengaruhi variabel prestasi belajar siswa sebesar 0,187 atau $18,7 \%$ dan sisanya sebesar 81,3 $\% \quad(100 \%-18,7 \%=81,3 \%)$ dipengaruhi oleh faktor lain yang tidak dikaji dalam penelitian ini seperti displin belajar, fasilitas belajar dan lingkungan sekolah.

\section{PEMBAHASAN}

\section{Pengaruh antara minat belajar terhadap prestasi belajar siswa pada mata pelajaran ekonomi bisnis kelas X SMK PGRI 2 Bojonegoro}

Berdasarkan hasil perhitungan diketahui bahwa terjadi pengaruh positif dan signifikan minat belajar terhadap prestasi belajar siswa. Hal ini dibuktikan dengan nilai uji $\mathrm{t}$, diperoleh hasil $t_{\text {hitung }}$ sebesar 3,599 dan $t_{\text {tabel }}$ sebesar 1,991 atau 3,599>1,991 pada taraf signifikan sebesar 0,001lebih kecil dari nilai $\alpha(0,05)$. Sehingga dapat disimpulkan $\mathrm{H}_{\mathrm{O}}$ ditolak dan $\mathrm{H}_{\mathrm{a}}$ diterima yang artinyabahwa" Ada pengaruh positif dan signifikan antara minat belajar terhadap prestasi belajar siswa pada mata pelajaran ekonomi bisnis kelas $\mathrm{X}$ SMK PGRI 2 Bojonegoro". Dengan konstribusi minat belajar terhadap prestasi belajar siswa sebesar $(0,377)^{2}$ x $100 \%=14,2 \%$.

Dan berdasarkan keadaan subjek penelitian, bahwa didapat para siswa masih mempunyai minat belajar yang rendah. Hal ini dapat dilihat bahwa pada saat proses pembelajaran berlangsung, siswa masih belum bisa menjawab pertanyaan yang diajukan oleh guru karena mereka belum belajar sebelumnya. Semakin tinggi minat belajar yang dimiliki oleh siswa terhadap mata pelajaran yang ia minati, maka semakin tinggi pula prestasi belajar yang diperolehnya. Hal ini didukung oleh teori Djamarah (2008:157) yang menyebutkan bahwa "Minat belajar yang besar akan menghasilkan prestasi yang tinggi, sebaliknya kurangnya minat belajar akan menghasilkan prestasi belajar yang rendah".

Hal ini didukung penelitian dari Nurul Huda Sukaraja (2017) dengan judul " pengaruh minat belajar terhadap prestasi belajarbidang studi ekonomi siswa MA Al Fattah Sumbermulyo". Angka indeks korelasi minat belajar dengan prestasi belajar bidang studi ekonomi adalah 0,681. Dari hasil penelitian tersebut dapat disimpulkan bahwa minat belajar berpengaruh terhadap prestasi belajar bidang studi ekonomi di MA Al Fattah Sumbermulyo. 


\section{Pengaruh antara lingkungan} keluarga terhadap prestasi belajar siswa pada mata pelajaran ekonomi bisnis kelas $\mathrm{X}$ SMK PGRI 2 Bojonegoro

Dan hasil perhitungan hipotesis kedua melalui uji signifikansi secara parsial (uji t) diketahui bahwa terjadi pengaruh positif dan signifikan lingkungan keluarga terhadap prestasi belajar siswa. Hal ini dibuktikan dengan hasil nilai $t_{\text {hitung }}$ sebesar 3,537 dan $t_{\text {tabel }}$ sebesar 1,991 atau 3,537>1,991 pada taraf signifikan sebesar 0,001 lebih kecil dari nilai $\alpha(0,05)$. Sehingga dapat disimpulkan $\mathrm{H}_{\mathrm{O}}$ ditolak dan $\mathrm{H}_{\mathrm{a}}$ diterima yang artinya bahwa "Ada pengaruh positif dan signifikan antara lingkungan keluarga terhadap prestasi belajar siswa pada mata pelajaran ekonomi bisnis kelas X SMK PGRI 2 Bojonegoro". Dengan besarnya kontribusi lingkungan keluarga terhadap prestasi belajar siswa sebesar $(0,372)^{2} \times 100 \%=13,8 \%$.

Keadaan subjek penelitian ini, para siswa tidak selalu dipenuhi kebutuhan fasilitas belajarnya seperti buku, tas dan peralatan sekolah oleh orang tuanya, sehingga mereka pun kurang semangat dalam belajar. Suasana rumah yang kurang nyaman, perhatian orang tua kepada anaknya untuk belajar kurang , bisa memngakibatkan prestasi belajar anak kurang optimal. Hal ini didukung teori dari Hamalik (2001: 194) yang menyatakan bahwa keadaan keluarga yang kurang harmonis, orang tua kurang perhatian terhadap prestasi belajar siswa dan keadaan ekonomi yang lemah atau berlebihan bisa menyebabkan turunnya prestasi belajar anak.

Hal ini juga didukung penelitian yang dilakukan oleh Mira Araimi (2015) yang berjudul "pengaruh lingkungan keluarga terhadap prestasi belajar siswa kelas XI SMA Negeri 3 Peusangan". Hasil penelitian diperoleh adalah 4,17 sedangkan harga $t_{\text {tabel }}$ didapatkan sebesar 2,03 yang berarti $t_{\text {hitung }} \geq t_{\text {tabel }}$ yaitu $4,17 \geq$ 2,03. Dengan demikian Ha diterima Ho ditolak, maka dapat disimpulkan bahwa " Ada pengaruh yang signifikan lingkungan keluarga terhadap prestasi belajar siswa kelas XI SMA Negeri 3 Peusangan".

\section{Pengaruh antara minat belajar dan lingkungan keluarga terhadap prestasi belajar siswa pada mata pelajaran ekonomi bisnis kelas X SMK PGRI 2 Bojonegoro}

Menurut Hamalik (2001: 110) yang menyatakan bahwa belajar tanpa adanya minat kiranya sulit untuk mencapai keberhasilan secara optimal. Dan menurut Hasbullah (2009: 38) menyatakan bahwa lingkungan keluarga merupakan lingkungan pendidikan yang pertama, karena dalam lingkungan keluarga inilah anak pertama-tama mendapatkan pendidikan.

Berdasarkan hasil perhitungan hipotesis ketiga diperoleh hasil $F_{\text {hitung }}$ sebesar 8,996 dan $F_{\text {tabel }}$ sebesar 3,114 atau 8,996>3,114 pada taraf signifikan sebesar 0,000 lebih kecil dari nilai $\alpha(0,05)$. Sehingga dapat disimpulkan $\mathrm{H}_{\mathrm{O}}$ ditolak dan $\mathrm{H}_{\mathrm{a}}$ diterima yang artinya bahwa" Ada pengaruh secara simultan antara minat belajar dan lingkungan keluarga terhadap prestasi belajar siswa pada mata pelajaran ekonomi bisnis kelas $\mathrm{X}$ SMK PGRI 2 Bojonegoro". Dengan konstribusi variabel independen secara bersama-sama mempengaruhi variabel dependen sebesar 18,7\%.

Hal ini menunjukkan bahwa minat belajar mempunyai peranan yang sangat penting dalam proses belajar seorang siswa.Seorang siswa yang mempunyai minat belajar yang tinggi serta tumbuh dalam dirinya, dan juga memiliki 
lingkungan keluarga yang nyaman serta mendukung untuk terus tetap semangat dalam kegiatan belajar, maka hal ini akan sangat mendukung tercapainya prestasi belajar secara optimal dan maksimal.

\section{PENUTUP}

\section{Kesimpulan}

Berdasarkan hasil penelitian dan pembahasan yang telah diuraikan diatas, maka dapat diambil kesimpulan sebagai berikut :

1. Ada pengaruh positif dan signifikan antara minat belajar terhadap prestasi belajar siswa pada mata pelajaran ekonomi bisnis kelas X SMK PGRI 2 Bojonegoro. Dengan nilai signifikan minat belajar sebesar 0,001 lebih kecil dari nilai probalitas sebesar 0,05 atau 0,001 <0,05 dan dengan perbandingan hasil $t_{\text {hitung }}$ sebesar 3,599 dan $t_{\text {tabel }}$ sebesar 1,991 atau 3,599 > 1,991.

2. Ada pengaruh positif dan signifikan antara lingkungan keluarga terhadap prestasi belajar siswa pada mata pelajaran ekonomi bisnis kelas $\mathrm{X}$ SMK PGRI 2 Bojonegoro. Dengan nilai signifikansi lingkungan keluarga sebesar 0,001 lebih kecil dari nilai probalitas sebesar 0,05 atau $0,001<0,05$ dan dengan perbandingan hasil $t_{\text {hitung }}$ sebesar 3,537 dan $t_{\text {tabel }}$ sebesar 1,991 atau $3,537>1,991$.

3. Ada pengaruh positif dan signifikan antara minat belajar dan lingkungan keluarga secara simultan terhadap prestasi belajar siswa pada mata pelajaran ekonomi bisnis kelas $\mathrm{X}$ SMK PGRI 2 Bojonegoro. Dengan nilai signifikansi sebesar 0,000 lebih kecil dari nilai probalitas sebesar 0,05 atau $0,000<0,05$ dan dengan perbandingan hasil dari

$F_{\text {hitung }}$ sebesar $\quad 8,996$

$>F_{\text {tabel }}$ sebesar 3,114 atau $(8,996$ $>3,114)$.

\section{Saran}

Saran yang dapat diberikan berdasarkan hasil kesimpulan yang telah diuraikan diatas adalah sebagai berikut :

1. Siswa diharapkan untuk dapat meningkatkan minat belajar yang lebih tinggi . Dan tak hanya itu siswa diharapkan untuk lebih mengetahui atau memahami keadaan lingkungan keluarganya, sehingga nantinya siswa dapat ikut serta dalam membentuk keadaan lingkungan keluarga yang baik.

2. Orang tua diharapkan dapat selalu aktif dalam memberikan dorongan dan perhatian yang besar pada anak dalam belajar baik di rumah maupun di sekolah, memberikan bimbingan dan teguran serta menyediakan fasilitas belajar yang memadai bagi anak di rumah, dan menciptakan lingkungan keluarga yang kondusif dan nyaman, sehingga anak dapat mencapai prestasi belajar yang lebih tinggi dan optimal .

3. Bagi pihak sekolah perlu melakukan peningkatan hubungan kerjasama yang lebih baik antara pihak sekolah dengan orang tua. Dan untuk guru khususnya guru mata pelajaran ekonomi bisnis perlu menciptakan strategi pembelajaran yang bervariasi agar minat belajar siswa juga meningkat saat proses pembelajaran berlangsung. 
4. Bagi peneliti selanjutnya diharapkan dapat mempertimbangkan variasi populasi yang beskala lebih besar lagi dan meneliti variabel lain yang tidak diteliti dalam penelitian ini.

\section{DAFTAR PUSTAKA}

Djamarah, S.B.(2008). Prestasi belajar. Jakarta : Rineka Cipta.

Ghozali, I.(2011). Aplikasi Analisis Multivariate dengan Program IBM SPSS19. Semarang : Badan Penerbit Universitas Diponegoro.

Hasbullah, (2009). Dasar-Dasar Ilmu Pendidikan. Jakarta : Rajawali Pers

Hamalik, O. (2001). Proses Belajar Mengajar. Jakarta: PT Bumi Aksara.

Araimi, M. (2015). Pengaruh Lingkungan Keluarga Terhadap Prestasi Belajar Siswa kelas XI SMA Negeri 3 Peusangan. Universitas Almuslim

Slameto, .(2010). Belajar dan faktor faktor yang mempengaruhinya. Cetakan ke-5. Jakarta : Rineka Cipta. 
160 JURNAL PENDIDIKAN EDUTAMA, Vol 7, No1.Januari, 2020 